\title{
INTEGRATION IN LATVIA: FLOWS AND EBBS IN NATIONAL AND EUROPEAN CONTEXT
}

\author{
Juris Rozenvalds ${ }^{1}$
}

\begin{abstract}
Russian-speaking communities in the member states of the European Union (EU), especially the Baltic States and Germany, have earned special attention, in recent years, as subjects of important integration policies, on one hand, and the main targets of Russia's propagandist efforts, on the other. Because a significant part of Russian-speaking communities accepted these efforts, questions were raised concerning the effectiveness of previous integration policies to strengthen the national identity and invoke a feeling of political togetherness. Thus the factors fostering and triggering integration and the relations between civic and ethnocultural components of integration are of wide interest. This paper presents a case study of Latvia, as a country with the highest share of Russian-speaking citizens among the EU member states and a clear prevalence of ethnocultural components in its integration policies in recent years. The study examines the successes and failures of the integration policies of Latvia during the last twenty-five years, using mainly direct observations and sociological data collected during the last twenty years. The results show that language knowledge, citizenship status, and socioeconomic conditions play an important role in integration. In addition, these factors appear more effective with development of inclusive political practices and civil society structures, cooperative discourse, and facilitation of mutual trust between ethnolinguistic communities.
\end{abstract}

UDC Classification: 323.1, DOI: http://dx.doi.org/10.12955/cbup.v4.787

Keywords: integration, Russian-speakers, inclusive politics, cooperative discourse.

\section{Introduction}

During recent years, Europe has faced several interconnected challenges with respect to immigration, which has become one of the major topics in political and everyday discourse. First, the scale and speed of immigration has dramatically risen. In the last two decades, about 26 million people have migrated to the European Union (EU) from outside Europe, especially from Africa and the Middle East, and their specific weight in the EU member states is now close to 7\% (KING, 2015, p. 11). In addition, illegal immigrants add weight, with about 1.8 million illegal crossings of the borders into the EU recorded in 2015 alone (FRONTEX, 2016). Overall, this migration increases the importance of integration policies for years to come. Second, there have been serious problems with respect to the integration of descendants from immigrants who had arrived in Western Europe decades previously (Weaver, 2010) . Compared to today, this past era had different national models of integration and understandings of relations between civic and cultural components of integration. These varied from the French "republican" model to multicultural model in Great Britain and Netherlands, and the ethnonational model in several East-European countries (van Reekum, 2012). All models met with considerable difficulties and led to controversial consequences. This has been evident, especially in "old" immigration countries, in the social unrest, further development of segregated neighborhoods, rise of Islamic fundamentalism, and radicalization of a substantial part of the immigrant populations (Koopmans, 2013). Several terrorist attacks in major European cities were organized and carried out by citizens of neighboring countries. This refers, among others, to the notorious London bombings of 2005, and the recent terrorist attacks in Paris and Brussels. During the last 10 to 15 years, failure of confidence in integration policies has become widespread across most European countries. Finally, some immigrant communities, which were considered positive examples of integration in a number of Western European countries, posed new unexpected challenges, to a great extent, due to changes in relations between Russia and the West. An example is the Russian-speaking community of Germany. Although Representative of the German Government, Hartmut Koschyk, in January 2016, in an interview with "Deutsche Welle", called the integration of Russian Germans as "outstanding" (Jolkver, 2016). Because a significant part of the Russian-speaking community in Germany accepted the Kremlin propaganda and supported xenophobic slogans in connection with the notorious "Lisa case", questions were raised concerning the effectiveness of previous integration policies.

This paper is based on the assumption that the Latvian case, with decades of experience in interaction between two large ethnolinguistic communities, Latvian and Russian, and the dramatic increase in

\footnotetext{
${ }^{1}$ Juris Rozenvalds, University of Latvia, Riga, Latvia, Juris.Rozenvalds@lu.lv
} 
propagandist activities of Russia, especially towards the Russian-speaking population after annexation of Crimea, may be useful for understanding factors determining a successful integration. The following working definition of social integration will be used: "social integration is a process of unifying society by strengthening participation, intercultural contact, and non-discrimination." (Muižnieks, 2010, p. 31). The study examines the relations between civic and cultural or linguistic aspects of social integration and whether there are any additional factors, important for facilitating a sense of belonging for migrants and their descendants. Successes and failures of integration policies in Latvia during the last twenty-five years are analyzed, mainly from direct observation and sociological data collected during the last twenty years.

\section{Integration "From Below" and Integration "From Above"}

During the "Soviet time", Latvia was a main target of internal migration within the Soviet Union. As a result, the specific weight of ethnic Russians, shortly before the breakdown of the Soviet Union, was a third of the population. During the last twenty-five years, the specific weight of ethnic Russians decreased, and in 2011 Russians comprised 26.9\% of inhabitants of Latvia, with $33.7 \%$ of the inhabitants who spoke Russian at home (CSBL, 2016, p. 103). From a EU angle, it is noted that Latvia, among the member states of the European Union, had the highest share of inhabitants identifying themselves as having a language of "no official status in the EU" as their mother tongue. In this respect, Latvia with $27 \%$ was followed by Estonia (18\%), Bulgaria (11\%), Germany (8\%), and Lithuania (7\%; EC, 2006, p. 8). The Russian-speaking community in Latvia was not only the largest in the Baltic states, but the Russian-speaking community in Latvia demonstrated the greatest confidence in their strength in relations with other ethnolinguistic groups as compared to Russian speakers in other Baltic states. As the study of Ehala and Zabrodskaja (2011, p. 6) showed, their self-assessment, on a scale of 0 to 1 , was 0.51 whereas the self-assessments of Russian-speaking communities in Lithuania and Estonia were 0.49 and 0.45 , respectively.

Integration in Latvia in the years during, and following, the "Singing revolution" gave rise to a contradictory and, sometimes, paradoxical picture. First, the "Singing revolution", as such, was a successful integrative effort and a success of the realistic platform of the Popular Front of Latvia (PFL), which was the largest and most influential national democratic organization in Latvia between 1988 and 1991. This platform was based on the renewal of independence being only possible through active support of members of all Latvia's ethnic groups, and the PFL placed enormous effort into satisfying the Russian-speaking audience. As a result, only 20 to $30 \%$ of Russian-speakers supported the efforts to renew the Soviet era status quo (Zepa, 1992) Secondly, there was a distinct difference between the spontaneous integration at the grass-root level ("integration from below") and the statesupported official integration policies of the state of Latvia ("integration from above"). There were several objective factors that facilitated the success of the spontaneous integration "from below", allowing it to avoid serious conflicts on ethnic grounds, e.g., demographic factors, such as, a comparatively high percentage of mixed marriages (CSBL, 2016), a lack of sharp differences between ethnolinguistic communities in the sense of social and economic standing (Hazans, 2010, p. 141), a substantial number of so-called "old Russians" (most of whom were already citizens of the Republic of Latvia before the war and who were aware of their ties to Latvia), a lack of major differences between Latvians and non-Latvians of Latvia in regard to civic values, and a substantial rise in the level of Latvian language knowledge among non-Latvians during the years of restored independent statehood. As a result of the aforementioned, an improvement in the bilingual segment of culture in Latvia was significantly greater than that in the neighboring Lithuania and Estonia, where it covered about $18 \%$ of population compared to Latvia with $40 \%$ (Ehala, 2012). Where properly used, the "from below" approach may be important for state integration policies, although this is yet to be realized.

\section{"Cultural Traumas" and Conflict of "Minority Feelings"}

Attitudes towards integration and understanding of the idea of integration among the main ethnolinguistic groups of Latvia were, to a great extent, formed within the context of two fundamental structures of collective consciousness, which crystalized from the Soviet time experience, namely, "cultural trauma" and "hope for return". "Hope for return" was the widespread intention to overcome the artificial isolation from the West caused by the Soviet occupation (Lauristin, 1997). For this goal, 
the majority of the Latvian society was ready for certain sacrifices and open to suggestions and pressure from the Western powers. The West had clearly linked membership in the EU and the political support of Latvia regarding the conflict situation between the West and Russia in 1997-1998 with measures in consolidating the society, and Western pressure influenced the Latvian political elite to set aside utopian hopes that were once widespread, at the beginning of the 1990s. These were hopes that postwar migrants would leave Latvia for the homelands of their ancestors, thus resolving the integration issue. On the contrary, because of this pressure integration became the "unloved child" of the Latvian ruling political elite, and thus, implementation of integration and consolidation measures became fragmented. "Flows" were followed by "ebbs", integration policies were inconsistent, and successes in some fields were usually followed by fallbacks or nationalists" "revenge" attempts in others.

The notion of "cultural trauma" was a collective shock theory arising from changes that were "sudden and rapid, radical, deep, touching the core, perceived as imposed, exogenous, coming from the outside" (Sztompka, 2000, p. 452). This notion appeared extremely helpful for conceptualizing the collective experience (although for different reasons) of the two largest ethnolinguistic groups of Latvia. For Russian-speakers "cultural trauma" was caused by loss of Soviet-era privileges, an "elder brother" position for the minority, and a necessity to realize for themselves who they were, i.e., a remnant of the Soviet empire or a minority with a goal to become an integrative part of a renewed country. For Latvians, it arose from experience of occupation, repressions after World War II, russification, and threats to become a minority in their own homeland. Notably, the "minority complex" was widespread among Latvians and played a controversial role in social and political processes of the last quarter of a century. On the one hand, it created an extremely high level of mass participation during the years of the "singing revolution". On the other hand, it proved to be also viable when the situation substantially changed and Latvians started to play a leading role in political and economic life of the renewed state. As Ehala and Zabrodskaja (2011) stressed, the relative ethnic potential of Latvians (which is calculated by comparing the title nation's self-assessment with its assessment of the ethnic potential of the Russian-speaking minority) was attributed to Latvians having only a small lead over the Russian-speakers $(0.10)$ and was much lower for the respective numbers of Estonians $(0.23)$ and Lithuanians $(0.20 ;$ p. 30). As a result, both of the larger ethnolinguistic groups of Latvia showed insecurity, a sense of being threatened by their ethnolinguistic identity, and overall a conflict of minority feelings.

\section{As If They Would Not Be Here...}

A relatively low collective self-assessment, aforementioned "minority complex", expressed itself in the exclusionary political culture, as an attitude widespread among the Latvian part of society and the Latvian political elite that the post-war immigrants were not entitled to make decisions on strategic matters of Latvia's development. It was expressed in the mid-1990s as an inability of the general public to accept the idea of a political or civic nation (Hanovs, 2003). This attitude proved to be rather stable. In a 2013 survey, $60.3 \%$ of ethnic Latvian respondents agreed to the statement that the cultures of national minorities should be supported and strengthened in Latvia. At the same time, only $37.5 \%$ of respondents supported the statement that more active participation of ethnic minorities in decision making would be a "good thing" for Latvia (FSS, 2013). This widespread popular attitude was actively used by the ruling political elite and became a basis for the pronounced paternalism of the Latvian state integration policy. There was a tendency to resolve minority related issues without participation of minorities in the formulation of its goals and methods, on the one hand, and for the domination of ethnocultural components in state integration policies, on the other. The priority of Latvian ethnic values as the main precondition for consolidation of society has been strengthened over the last decade with its effect on consolidation of the Latvian society at least contradictory. As a 2013 survey showed, 97.6\% of Latvians and $78.4 \%$ of Russians agreed with the statement that all citizens of Latvia must speak Latvian language, whereas $90.9 \%$ of Latvians and only $43.1 \%$ of Russians supported the statement that the Latvian language and culture were the only foundations for consolidation (FSS, 2013). This was also reflected in the overall assessment of the state of ethnic relations. Although $59.3 \%$ of Latvian respondents and $57.2 \%$ of Russian-speakers of Latvia viewed the inter-ethnic relations in Latvia as satisfactory, and $21.2 \%$ of Latvians and $23.6 \%$ of non-Latvians as good, the share of respondents who assessed ethnic relations in Latvia as "bad" or "very bad" had substantially 
increased among Latvians from $5.7 \%$ in 2004 to $14.8 \%$ in 2014, and among Russians from 9.3 to 14.9 , respectively, over the last decade (FSS, 2014).

The state of Latvia was even less successful in political integration. First, the division of the political spectrum, along the ethnic lines of "Latvian" and "Russian" parts, was integral. Despite growing electoral support of parties oriented mainly at Russian-speaking voters, who had already tripled their share in parliamentary elections from $10 \%$ in 1993 to $20.1 \%$ in $2002,29.1 \%$ in 2011 , and $25.8 \%$ in 2014 (CECL, 2016), political representatives of the Russian-speaking electorate, who had formed the largest fraction during the last two tenures of Latvian parliament, are currently isolated and have no chance of becoming members of the ruling coalition. There are still more than $11.8 \%$ of inhabitants of Latvia ("non-citizens") who lack political citizenship. Unlike neighboring Estonia, they cannot take part in municipal elections. Non-citizenship problems in Latvia have a clear age dimension. Among inhabitants aged 62 to 66 years $71 \%$ are citizens, while for those 26 to 32 years up to $91 \%$ and for those 17 to 22 years $94 \%$ are citizens (OCMA, 2016). However, legal attachment to the state does not significantly alter political behavior of young Russian-speakers, and this, to a great extent, is determined by the solidarity of the older generation.

\section{Basis for Attachment}

As Birka (2013) indicated in her study of integration and sense of belonging, citizenship of Latvia and knowledge and use of the Latvian language have no positive correlation with the sense of belonging for Russian-speaking youth in Latvia. In contrast, identification with the host society, favorable orientation towards the group, thinking in terms of commonality and not ethnicity, and a willingness to engage in communication have been positively correlated with a sense of belonging in Latvia (Birka, 2013).

The course and speed of integration in Latvia is substantially affected by the existence of two information spaces, Latvian and Russian (represented mainly by TV channels from Russia), with differing orientations, information sources, and lack of dialogue between them. The survey data showed that $77.8 \%$ of Latvian speakers and only $8.7 \%$ of Russian speakers prefer Latvia's TV channels, whereas Russia's TV channels were preferred by $84.1 \%$ of Russian-speakers and $15.2 \%$ of Latvian-speakers (FSS, 2014). Proposals to launch a TV channel aimed at the Russian-speaking minority were rejected because of opposition from nationalist forces (PBL, 2015). In a situation where Russian-speaking audiences feel estranged from the majority and do not trust Latvian public TV because they view it as official state propaganda, space is open for interpretation of the history and current events in Latvia and abroad that are broadcast by Kremlin's controlled mass media.

\section{Conclusion}

The Latvian experience shows that language knowledge, citizenship status, and socioeconomic conditions and benefits undoubtedly play an important role in integration. Therefore, it is a basis for a cohesive society. However, these factors alone are seemingly insufficient for ensuring social cohesion without growth of intercultural competence, facilitation of communication and mutual trust between communities and power structures. Other essentials include the launching of more active information policies on a national and European level (e.g., European and national Russian-speaking TV channels) and developing inclusive political practices and civil society structures to overcome ethnic, cultural, and religious barriers.

\section{References}

Birka, I. (2013). "Integration and Sense of Belonging - Case Study Latvia." Doctoral thesis. University of Latvia, Riga. CECL (2016). The Central Election Commission of Latvia. Retrieved on May 6, 2016 from: www.cvk.lv

CSBL (2016). Central Statistical Bureau of Latvia. Retrieved on May 6, 2016 from: http://data.csb.gov.lv/pxweb/lv/Sociala/Sociala_ikgad_iedz_laulibas/IL0051.px/?rxid=562c2205-ba57-4130-b63a6991f49ab6fe

Ehala, M. \& Zabrodskaja, A. (2011). Etnolingvisticheskaya vital'nost' etnicheskikh grupp stran Baltii. Diaspory, 1. [Ethnolinguistic vitality of ethnic groups of Baltic states. Diaspora 1].

Ehala, M. (2012). "Ethnic and National Identity in the Baltic States". Presentation at the seminar on preparation of the collective monograph, Faculty of Social Sciences, University of Latvia (Riga), November 23.

EC (2006). European Commission. Europeans and Their Languages. Special Eurobarometer 243/ Wave 64.3. 
FRONTEX (2016). Greece and Italy continued to face unprecedented number of migrants in December. Retrieved on June, 14, 2016 from: http://frontex.europa.eu/news/greece-and-italy-continued-to-face-unprecedented-number-of-migrants-indecember-0BbBRd

FSS (2013). Faculty of Social Sciences, University of Latvia, and TNS Latvia. "Survey of Latvian Residents lnequality, Integration, and Sustainable Development", May-June, 2013, n=1001.

FSS (2014). Faculty of Social Sciences, University of Latvia, SKDS. Survey of Latvian residents for the "Audit of Democracy 2005-2014", April, 2014, n=1000.

Hanovs, D.(2003). Politiskā kultūra Latvijā : atvērta vai slēgta koncepcija? [Political culture in Latvia: open or closed conception?]. In Providus, 14.10.2003. Retrieved on September, 9, 2016 from: http://providus.lv/article/politiska-kulturalatvija-atverta-vai-slegta-koncepcija

Hazans, M. (2010). "Ethnic Minorities in the Latvian Labour Market, 1997-2009: Outcomes, Integration Drivers and Barriers". Pp. 125-158 in How Integrated is Latvian Society? An Audit of Successes, Failures, and Challenges, edited by Nils Muižnieks. Riga: University of Latvia Press.

Jolkver, N. (2016). "Koschyk: "Aussiedler helfen Flüchtlingen" [„Koschyk: "Repatriates help refugees"]". Deutsche Welle, Jan. 266. Retrieved on March 6, 2016 from: http://www.dw.com/de/koschyk-aussiedler-helfen-flüchtlingen/a-19009755

KING (2015). Knowledge for Integration Governance. Evidence on migrants' integration in Europe. Ed by G. Gilardoni, M. D'Odorico and D. Carrillo. Fondazione ISMU, 2015.

Koopmans, R. (2013). Fundamentalismus and Fremdenfeindlichkeit. Muslime und Christen im europäischen Vergleich.[ Fundamentalism and out-group hostility] Pp. 21-25 in WZB Mitteilungen, Hft. 142, December 2013. Retrieved on September 9, 2016 from: https://www.wzb.eu/sites/default/files/publikationen/wzb_mitteilungen/wm142gesamt.pdf

Lauristin M. (1997) „Contexts of Transition”. In: Lauristin M., et. al. (eds.) Return to the Western World. Cultural and Political perspectives of the Estonian Post-Communist Transition. Tartu University press: Tartu.

PBL, (2015). Finance Ministry frowns at plan for state Russian-language channel. Public Broadcasting of Latvia, March, 30 , 2015. Retrieved on September, 9, 2016 from: http://www.lsm.lv/en/article/politics/finance-ministry-frowns-at-plan-for-staterussian-language-channel.a123458/

Muižnieks, N. (2010). "Social Integration: A Brief History of an Idea". p. 15-32 in How Integrated is Latvian Society? An Audit of Successes, Failures, and Challenges, edited by Nils Muižnieks. Riga: University of Latvia Press.

OCMA (2016). The Office of Citizenship and Migration Affairs, Republic of Latvia. Retrieved on May 6, 2016 from: http://www.pmlp.gov.lv/lv/ assets/documents/statistika/IRD2016/ISVG_Latvija_pec_DZGada_VPD.pdf

Sztompka, P. (2000). “Cultural Trauma: The Other Face of Social Change.” European Journal of Social Theory 3: 449-466.

Van Reekum, R., Duyvendak, J.W., Bertossi, Ch. (2012). National models of integration and the crisis of multiculturalism: a critical comparative perspective, Patterns of Prejudice, 46:5, 417-426.

Weaver, M. (2010). Angela Merkel: German multiculturalism has 'utterly failed'. The Guardian, 17 October 2010. Retrieved on September 9 from: https://www.theguardian.com/world/2010/oct/17/angela-merkel-german-multiculturalism-failed

Zepa, B. (1992), Sabiedriskā dome pārejas periodā Latvijā: latviešu un cittautiešu uzskatu dinamika (1989-1992) [ Transitional period public opinion in Latvia: dinamic of views of Latvians and reprtesentatives of other ethnic groups (19891992)], Latvijas Zinātņu akadēmijas vēstis. A dạ̦a, 10 (543), p. 22. 